\title{
Scholars and Literati at the Danzig Research Society (1743-1800)
}

\author{
David de la Croix $\quad$ Maximilian Ganterer \\ IRES/LIDAM, UCLouvain
}

This note is a summary description of the set of scholars and literati who participated in the activities of the Danzig Research Society in Gdańsk (Pomerania, Poland) from its inception in 1743 to the eve of the Industrial Revolution (1800).

\section{THE ACADEMY}

Inspired by the emergence of several research societies in Europe during the seventeenth century and by the scientific work of Christian Wolff (1679-1754), a distinguished philosopher and scientist during the Age of Enlightenment (Hettche and Dyck 2019), a small group of doctors, priests, and public officials founded the Danzig Research Society. Focusing at the beginning on replicating other scholars' experiments, the Society later also engaged in astronomy, and maintained its own observatory. Besides its research activities, the Society built up a reputation for its exquisite collection of books, instruments, and biological artefacts, which was visited by academics and aristocrats alike.

\section{SOURCES}

The inception of the Research Society and its development, as well as its members, are well described in the Essay in Honour of the Danzig Research Society on the occasion of its 150th anniversary written by Schumann (1892). The essay provides a list of all the names of its members, and for the more influential members, it contains a short biography as well. Recently, Banditt (2018) published an essay on the Danzig Research Society, and conducted additional research to better identify some of its members. Using the information provided by Marc Banditt, we completed some place and date of birth for less known members. Finally, some missing information has been filled in, when available, by means of the database by the German National Library (2020).

\section{SOME STATISTICS}

Table 1 shows some descriptive statistics. There are 138 scholars and literati. This number includes both the local and the corresponding members of the academy. The year of birth is known for $92 \%$ of them. The mean age at appointment is 37.9 years. The mean age at death is 64 years. The birthplace is known for $85.5 \%$ of the individuals. The median distance between birth and Danzig is $15 \mathrm{~km}$, reflecting that a majority of the members come the city of Danzig and its vicinity. 37.7\% of the scholars have a Wikipedia page (in some language), and $66.7 \%$ of them have left a footprint in the catalogues of the libraries of the world, Worldcat, either by having published some work, or by having been the subject of published books and articles.

\section{FIELDS}

Figure 1 shows the relative importance of fields, broadly defined. The unofficial name of the Danzig Research Society was Societas physicae experimentalis, which explains why many of the scholars at the Society carried out research in the natural sciences. Another vital research area at Danzig was 


\begin{tabular}{ccccccc}
\hline \multicolumn{2}{c}{$\begin{array}{c}\text { Period } \\
\text { Start }\end{array}$} & End & nb. & \% birth year & mean age & mean age \\
known & at nomin. & $\begin{array}{c}\text { exp. age } \\
\text { at death }\end{array}$ & at death \\
\hline 1734 & 1800 & 138 & 92 & 37.9 & 64 & 62.8 \\
\hline & & & $\begin{array}{c}\text { \% birthplace } \\
\text { known }\end{array}$ & $\begin{array}{c}\text { median distance } \\
\text { birth-institution }\end{array}$ & $\begin{array}{c}\text { \% with } \\
\text { Wikipedia }\end{array}$ & $\begin{array}{c}\text { \% with } \\
\text { Worldcat }\end{array}$ \\
\hline 1734 & 1800 & & 85.5 & 15 & 37.7 & 66.7 \\
\hline
\end{tabular}

Table 1: Summary statistics

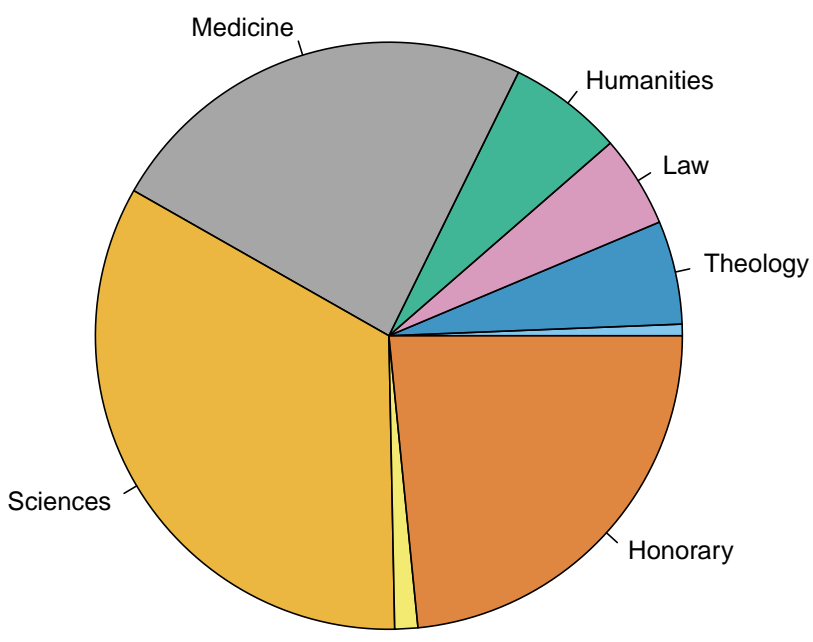

Figure 1: Broad fields at Danzig

Medicine and, in particular, the science of botany has to be mentioned. The relatively large scientific collections of the Society were built from donations by various honorary members who left their private collections to the Society as a gift or after their death.

\section{Place of Birth}

Figure 2 is a plot of the places of birth of all the ordinary members of the Society of Danzig. Figure 2 gives the same information for the corresponding members. It shows the European character of the society, thanks to its corresponding members.

\section{HUMAN CAPITAL OF SCHOLARS AND LITERATI}

For each person in the database we compute a heuristic human capital index, identified by combining information from Worldcat and Wikipedia using a principal component analysis. Details are given in the Appendix. Figure 4 shows the names of all the scholars with a positive human capital index. The vertical green lines (rug plot) show the distribution of all scholars, including the obscure ones, over time.

The pattern shows the problems that the Society faced after 1760 quite clearly. The original goal of the Society - replicating Christian Wolff's experiments- had been accomplished. Moreover, some of the founders and rather active members died or entered old age around this time, and were not replaced by equivalent scholars. 


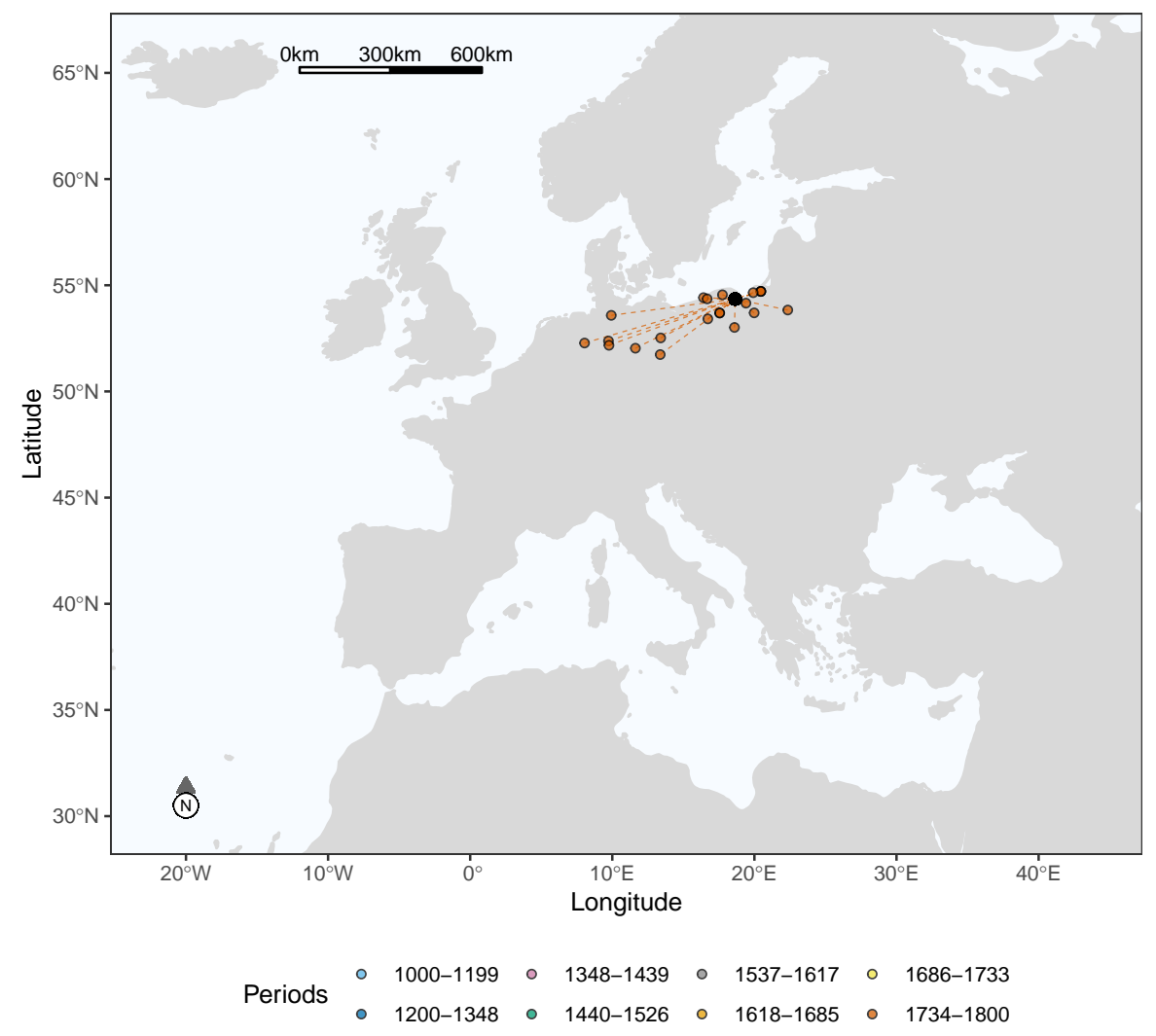

Figure 2: Place of birth of the scholars and literati at the Society of Danzig - ordinary members

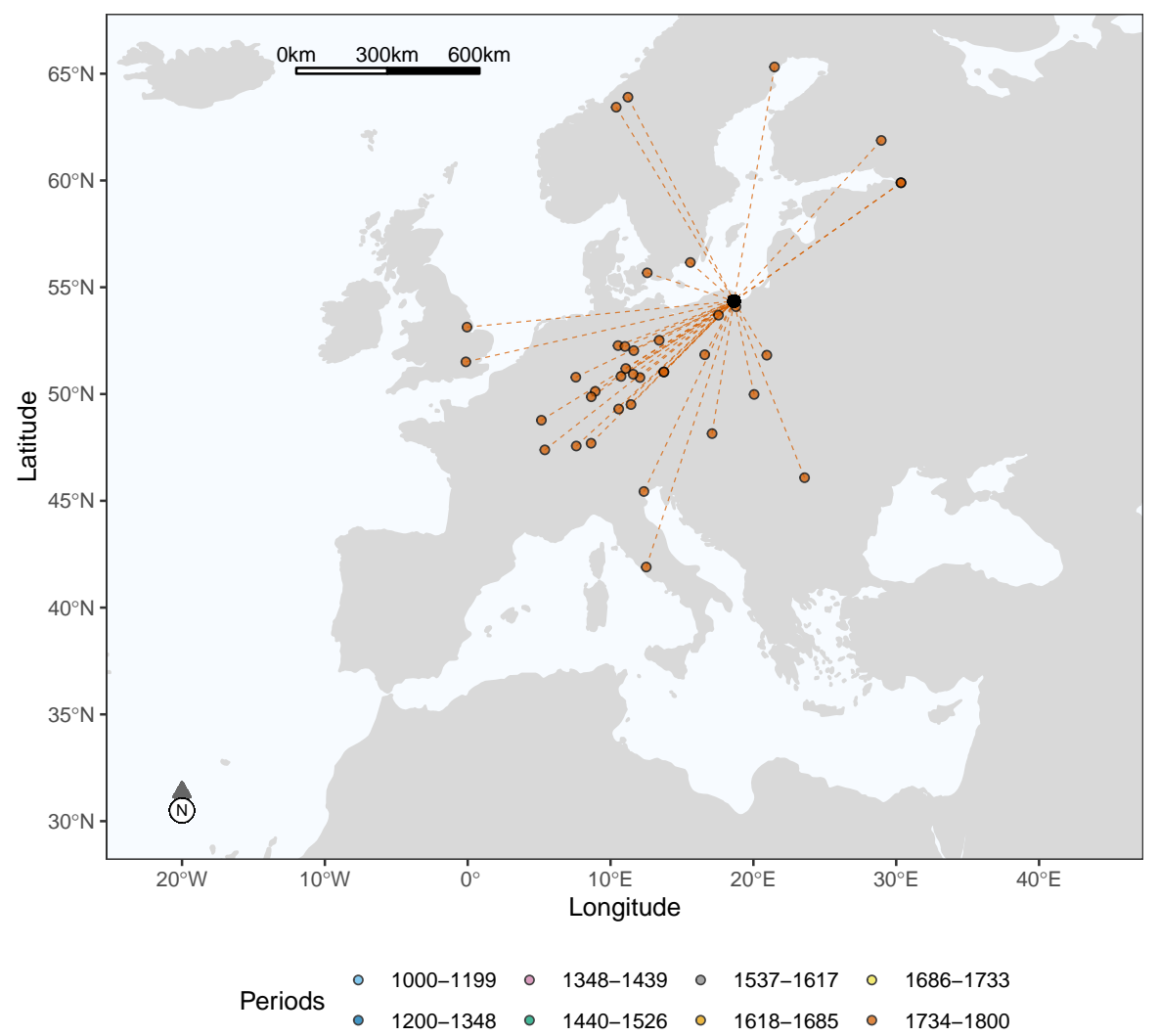

Figure 3: Place of birth of the scholars and literati at the Society of Danzig - corresponding members 


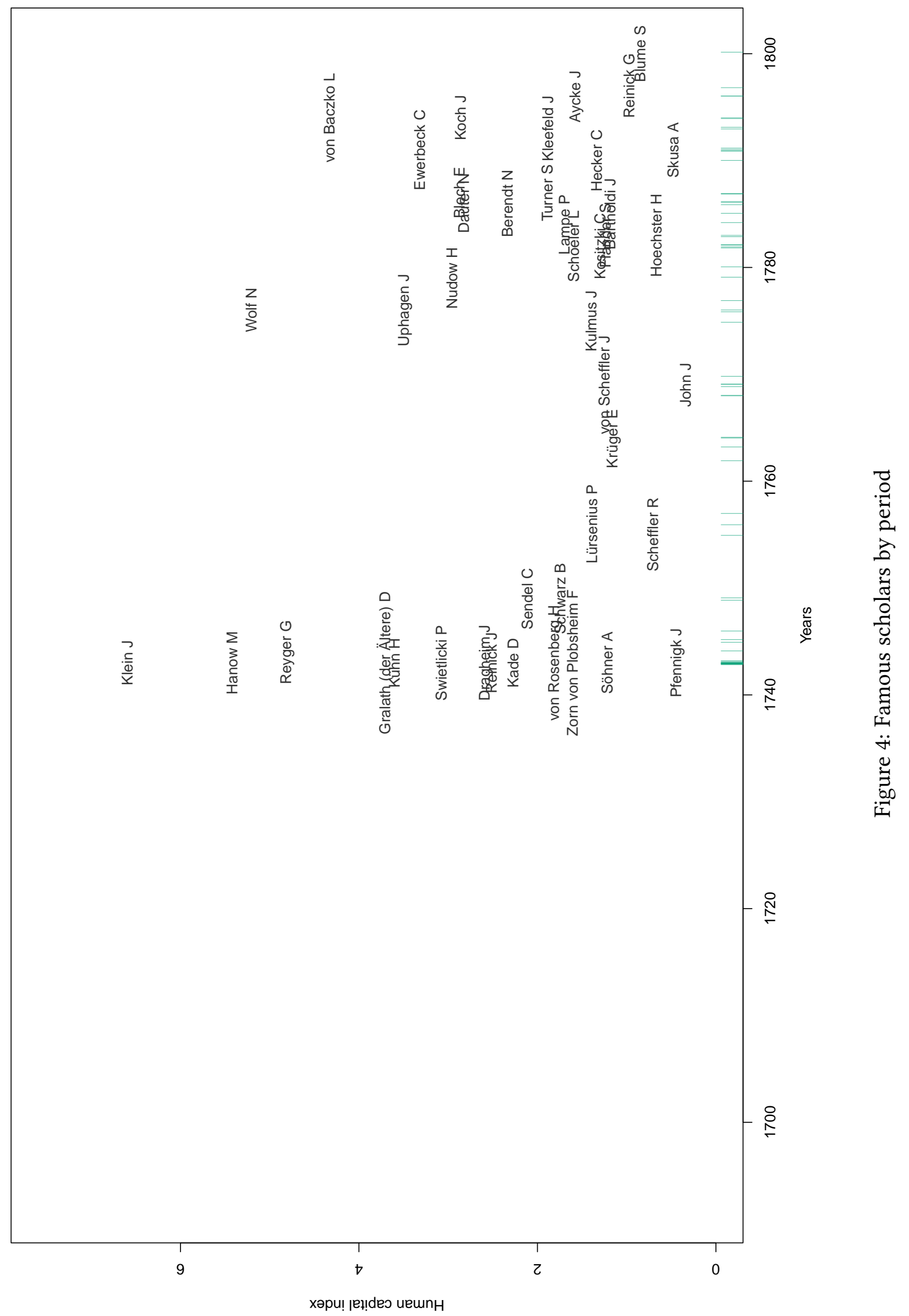




\section{TOP 6 SCHOLARS}

A brief overview of the six scholars with the highest human capital index follows.

Jakob Theodor Klein (Kaliningrad (Königsberg) 1685 - Gdansk (Danzig) 1759) was one of the founders of the Society of Danzig. Although he studied law, Klein conducted research primarily on the science of plants and zoology.

His most important contribution was a classification of animals that was easy to understand because it was only based on the obvious appearance of the animals. In addition, he was an enthusiastic collector of natural specimens, which he partly sold to the nobility and partly gave to the Danzig Research Society.

Michael Christophorus Hanow (Samborsko 1695 - Gdansk (Danzig) 1773) was a member of the Danzig Research Society since its inception. He made contributions to several research fields, among which law, mathematics, and philosophy. His research was published inter alia by himself in a journal that he released once a week, and which contained meteorological observations besides his academic work.

Nathaniel Matthew Wolf (Chojnice (Konitz) 1724 - Gdansk (Danzig) 1784) was a physician who was highly renowned all across Europe. He was an active doctor in particular in modernday Poland, Italy, and England. As a doctor, he was very inventive and liked to use new techniques as for example vaccination against smallpox. Besides his medical activities, he occupied himself with studies on zoology and astronomy. Wolf financially contributed to the construction of the Danzig observatory. Moreover, in order to ensure that astronomical research would continue in Danzig after his death, he bequeathed not only the observatory, but also money to the Danzig Research Society for hiring new astronomers after him.

Gottfried Reyger (Gdansk (Danzig) 1704 - Gdansk (Danzig) 1788) was wealthy enough to live most of his lifetime without having to work for money. All the free time he had was spent on research, and in particular research in botany, meteorology, and physics. The thermometer that he used for his observations was used in Danzig even after his death, and the temperature was measured in "Reygersche" units; $0^{\circ}$ "Reygersche" correspond to $48^{\circ}$ Fahrenheit and $9^{\circ}$ Celsius, for instance.

Daniel Gralath der Ältere (Gdansk (Danzig) 1708 - Gdansk (Danzig) 1767) was the decisive figure for the Danzig Research Society. He initiated the Society, convinced other scholars to join, and set up the first constitution for the Research Society. Gralath engaged in replicating Christian Wolff's experiments (1679-1754), but beyond these replications, he conducted his own experiments with electricity as well. He wrote a book on the history of electricity which was cited until late in the nineteenth century.

Heinrich Kühn (Kaliningrad (Königsberg) 1690 - Gdansk (Danzig) 1769) was a mathematician and physicist. In one of his works, he analyzed how tides work, and especially why there is sometimes a rising and sometimes a falling tide. He published this work in a collection on the movement of water on earth, for which he won a prize at a society in Bordeaux in 1741 . However, since this work also contradicted the gravity of the moon as established by Newton, and there were some errors in his analyses, he was regarded as a rather bizarre scholar by other academics.

\section{RELATED SCHOLARS}

Beyond those who were ordinary members of the Society, several individuals were related to it through foreign membership. These scholars are counted to establish all figures but Figure 4. One related scholar with a high human capital index is featured below. 
Johann Ernst Immanuel Walch (Jena 1725 - Jena 1778) was a professor and director of the Latin Society in Jena and foreign fellow of several research societies across Europe, among which the Danzig Research Society. He studied the classics, and traveled across Europe to visit libraries and museums. Besides languages, he was also interested in antiquities, and since he was very religious, especially in religious antiquities. His collection of natural specimens is regarded as one of the first of its kind in Germany. His interest in natural specimens is also documented in his publication of a series of journals called The Naturalist (Michaud 1811).

\section{ANECDOTES}

The Society was very enthusiastic in their experiments with an air pump that caused animals to suffer. Many animals died because the Society deprived them from air. Once, a fish was deprived until its stomach came out of its mouth. In another instance, the Society killed a hen in order to try to revive it by pumping air into it, which failed.

Due to the fact that he had much spare time, Gottfried Reyger (1704 - 1788) carried out numerous experiments. In particular, he enjoyed cooking bones with the high-pressure cooker created by Denis Papin (1647 - 1713). Unfortunately, Reyger did not always keep an eye on the cooking, and thus the cooker exploded once. It was only by sheer luck that no one was close to it, and hence only the building of the Society was somewhat damaged.

\section{APPENDIX}

The individual human capital index $q_{i}$ of an individual $i$ is given by:

$$
\begin{aligned}
q_{i}= & -1.76+0.43 \ln (\mathrm{nb} . \text { characters of the longest Wikipedia page }) \\
& +0.40 \ln (\mathrm{nb} . \text { wikipedia pages in different languages })+0.47 \ln (\mathrm{nb} . \text { works in Worldcat }) \\
& +0.46 \ln (\mathrm{nb} . \text { publication languages in Worldcat })+0.47 \ln (\mathrm{nb} \text {. library holdings in Worldcat })
\end{aligned}
$$

We assume that having no Wikipedia page is similar to having one page with a length of 60 characters and that having no Worldcat page is similar to having a page with one work in one language held by one library. The constant -1.76 normalizes $q_{i}$ at 0 when there is neither a Wikipedia page, nor a Worldcat page. The weights $(0.43,0.40$, etc $)$ are obtained from the first principal component of the five indicators (De la Croix et al. 2020).

\section{ACKNOWLEDGMENTS}

This project has received funding from the European Research Council (ERC) under the European Union's Horizon 2020 research and innovation programme, under grant agreement No 883033 "Did elite human capital trigger the rise of the West? Insights from a new database of European scholars."

First version December 3, 2020. Updated September 22, 2021

\section{REFERENCES}

Banditt, Marc. 2018. Gelehrte-Republik-Gelehrtenrepublik. Der Strukturwandel der Naturforschenden Gesellschaft in Danzig 1743 bis 1820 und die Danziger Aufklärung. Wiesbaden: Harrassowitz Verlag.

De la Croix, David, Frédéric Docquier, Alice Fabre, and Robert Stelter. 2020. "The Academic Market and the Rise of Universities in Medieval and Early Modern Europe (1000-1800)." CEPR Discussion Paper 14509.

German National Library. 2020. https://portal.dnb.de/opac.htm. 
Hettche, Matt, and Corey Dyck. 2019. “"Christian Wolff".” In Winter 2019 edition, edited by Edward N. Zalta. The Stanford Encyclopedia of Philosophy.

Michaud, Joseph-François. 1811. Biographie universelle ancienne et moderne, 45 vols. Paris: Bureau de la Biographie Universelle.

Schumann, Eduard. 1892. Geschichte der Naturforschende Gesellschaft in Danzig. Danzig: Commissions-Verlag von Wilhelm Engelmann. 